\title{
6. Responsible conflict reporting: Rethinking the role of journalism in Fiji and other troubled Pacific societies
}

\begin{abstract}
ABSIRACI
This article moots the idea of 'responsible conflict reporting' in Fiji and the South Pacific. Prolonged conflict, including three coups since 1987, has resulted in a pattern of social and economic decline in Fiji. In Melanesia as a whole, internal conflict is seen as a major security threat. The proposed responsible conflict reporting framework can be seen as a response to these longstanding trends and concerns. The framework is informed by various concepts in conflict resolution, peace-building, peace journalism and development journalism. By fusing the appropriate themes from these related but disparate frameworks, responsible conflict reporting goes beyond typical media interventions that focus mostly on current 'hot conflicts' without adequately addressing their long-term, structural causes.
\end{abstract}

Keywords: conflict reporting, democracy, development journalism, normative models, peace-building, peace journalism

\section{SHAILENDRA SINGH}

\section{University of the South Pacific and University of Queensland}



In coming years, Pacific Island journalists, native and expatriate, without being subservient, will have to develop a style of operation that sees all the news, good and bad, get into print, yet making some allowances for Pacific Island sensibilities. They will have to learn how to get local leaders to accept criticism coolly and with the realisation that a free press must often be cruel to be kind. (In Brislin, 1979, p. 85) 
Keith-Reid was addressing a panel reviewing 'adversary' and 'cooperative' (developmental) press systems in the Pacific. The panel noted that the libertarian press system imported from Great Britain, Australia, New Zealand and the United States prevailed in the Pacific (Brislin, 1979). The wellness of this system was predicated on the availability of a 'multitude of possible voices' in the public forum. However, contemporary economics had 'undercut' the 'multitude-of-voices' foundation, compromising media's search for the 'truth'. The panel suggested that 'somewhere between the extremes of the purely adversarial and the purely developmental might lie a press system more suited for the Pacific' (Brislin, 1979), although it did not outline or advocate any specific model.

Since that 1979 meeting, there has been little follow-up discussion about contemporary Pacific press models to deal with contemporary issues. Instead, the libertarian system became entrenched, even as concerns about the impact of 'contemporary economics' on media's watchdog role intensified with globalisation (see Brislin, 2004; 2007).

This article argues that in light of the profound transformations of recent decades, it is timely to revive discussions about the changing role of journalism in a changing Pacific society. The article is focussed primarily on conflict reporting because internal conflict is regarded as the predominant threat to security and sustainable growth in the Pacific, particularly in Melanesia (AusAid, 2006; Hegarty, 2003). The article moots the idea of a responsible conflict reporting framework to focus on the root and structural causes of conflict, which normally involve developmental and socio-economic issues. The responsible conflict reporting framework is predicated on a national journalist/media survey and content analysis of Fiji's 2006 elections conducted by this researcher late in 2012 and in early 2013. The preliminary findings of this ongoing project are briefly discussed. The article concentrates on Fiji, but has relevance for other troubled Pacific Island countries in terms of future research and practice.

\section{Rationale}

This research is a response to long-standing calls for Pacific media to explore new paradigms for journalism rather than uncritically accept Western models (Brislin, 1979; Latu, 2010). The pre-eminent Pacific media scholar Professor David Robie (2013) believes Western news values exclude a range 
of perspectives, and that a developing and conflicted region like the Pacific warrants a more facilitative, inclusive and participatory approach.

Internationally, longstanding concerns about journalists' handling of conflict intensified as the number of clashes increased in the 1990s (Obijiofor, 2011, p. 245). The South Pacific has had its share of conflicts in recent decades, particularly countries like Fiji, Papua New Guinea, Tonga, Samoa, the Solomon Islands, and Vanuatu (Henderson \& Watson, 2005).

Media in these countries are often accused of exacerbating disagreements through reckless, ill-informed reporting (Iroga, 2008; Kiran, 2005; Moala, 2008). This tendency is often linked to a dominant journalistic paradigm that regards conflict as a premium news value with 'drama' and 'abundance of visuals' (Wolfsfeld, 1997, p. 68). This orientation is said to put both people and nations on a war footing. For example, a doctoral dissertation by Beyene Zenebe (2012) used comparative case studies and process tracing to show that media contributed to both the 1994 genocide in Rwanda and the 2007 violence in Kenya. If anything, such findings belie calls for a rethink on how media cover crises. As Hirst and Patching (2007) state:

In the global crises we face today, people are constantly asking; 'Is the news media doing a good job?' Given that we rely so heavily on the news media to keep us informed, we have the right to ask, 'Can the media respond effectively to those crises?' (Hirst and Patching, 2007, p. 3)

The proposed responsible conflict reporting is also inspired by regionallybased scholars like Professor Vijay Naidu (2005) who believe that managing political conflicts in divided societies is a collective task. Furthermore, organisations like the International Federation of Journalists, the world's largest organisation of journalists with more than 600,000 members in more than 100 countries, now requires reporters to be trained in conflict resolution, with the promotion of peace as their goal (Ellis, 2012).

In Fiji, conflict containment has been a decades-long challenge. Recurring political and ethnic differences coupled with developmental issues triggered four coups between 1987-2006 (Firth, 2001; Robie, 2011). Fiji's media predominantly frame conflict in primordial terms. The country's two major ethnic groups, indigenous Fijian and Indo-Fijians, are portrayed as the major adversaries, even though divisions also exist along class, region, religious and economic lines. Intra-ethnic divisions exist within both the larger ethnic categories (M. Howard, 1991; Robertson 2008). 
The Fiji media's alleged role in fuelling racial tensions has been used by the likes of the 2006 coup leader Voreqe Bainimarama to denounce free speech and justify the imposition of sweeping media censorship (Bainimarama: Free speech 'causes trouble', 2009). As an unelected Prime Minister Bainimarama may lack credibility in the eyes of some. But media also face occasional criticism from democratically-elected leaders, academics and civil society (Bale, 2003; Chaudhry, 1999; Devi, 1992; Schramm, 2003).

This article posits that media can, to a certain degree, weaken governments' case for intervention by being sensitive to public concerns about how they report conflict. Towards this end, the proposed responsible conflict reporting framework can be seen both as a response to public disquiet about media's handling of conflict and a buffer against the authoritarian tendencies of governments in the region.

\section{A few caveats}

At this stage, a few caveats are in order. First, responsible conflict reporting is not to be confused with the Bainimarama regime's 'journalism of hope', which restricts media to positive coverage of the military government (Media in Fiji told to adopt 'journalism of hope', 2009). To the contrary, responsible conflict reporting is predicated on a free media environment and open dialogue. Any media abuse or shortcomings are best addressed through regular debate, discussion, training and education rather than restrictive legislation.

Secondly, responsible conflict reporting is not to be seen as a substitute for conventional journalism, which has useful 'watchdog' functions if exercised in an ethical and accountable manner. Rather, the proposed framework is envisaged as a balancing or harmonising model existing within or alongside conventional journalism, adding additional scope to its traditional Fourth Estate role.

Thirdly, media are not the cause of conflict in Fiji, even if they are allegedly stimulated by it, accused of escalating it, and may thrive on it. In Fiji, conflict is rooted in colonialism, racially-based electoral systems, ethnicity, competition for scarce resources and a myriad of other issues (Firth, 2001). As Hamelink (2008) says, conflict is embedded in human nature. But if conflict as an inherent human trait cannot be eradicated, it can be contained and constructively dealt with (Kriesberg, 2007; Naidu, 2005).

Fourthly, media on their own accord cannot bring peace; society too 
has to want peace. As Fiji's former Deputy Prime Minister in the deposed People's Coalition government, Tupeni Baba (2005) states, if Fijian society is ever again to enjoy peace, a concerted national effort is required, and a vision needs to be enunciated (pp. 366-369). Baba's call is understandable; peace-building is extremely challenging in its own right. In Fiji, there are substantial impediments to overcome; an enduring colonial legacy of divide and rule, racial polarisation and lack of political will, to name a few (Baba, 2005; Chand, 2008; Firth, 2001; Naidu, 2005).

Fifth, media capacity in the region is generally weak (PMCF, 2005). In Fiji, media have to deal with censorship, a dearth of trained, qualified and experienced journalists, and comparatively low wages, leading to high staff turnover (PMCF, 2005). Providing training and educational opportunities, and changing entrenched newsroom culture and mindsets, will be difficult tasks to achieve.

But if change is difficult, it is not impossible if realistic goals are set, and if change is envisioned as a long-term strategy based on persistent efforts and incremental gains. As Dr Ganesh Chand (2008), Vice-Chancellor of Fiji National University and a former government minister writes, change in Fiji cannot 'take place in a day or a year', or over the 'next two decades even', simply because the 'base is so low to start with' (p. 202). Yet, Chand inspiringly states that:

Simply moving in the right direction is a sound objective. Going forward over the next two decades, it is the direction of travel that matters more. Even small movements but on a positive trajectory will give ordinary citizens fatigued by two decades of division and hostility greater purpose and happiness. (Chand, 2008, p. 202)

Difficult as it might be, change is necessary. As Chand says, Fiji has been through 'extremely' difficult times over the past two decades. Another 20 years of such difficulty will 'tear away the heart of the nation'.

Lastly, responsible conflict reporting is a work in progress. It is not being presented as a complete framework, or the full and final solution, and should not be viewed as such.

\section{Problematising the Fourth Estate}

Responsible conflict reporting needs to be prefaced by problematising media's Fourth Estate role, which is seen as vulnerable to the 'destructive' 
impact of unregulated market forces (Petley, 2011). In surmising models of liberal democracies and news systems of the US and UK, Canadian communications professor, Robert Hackett (2013), talks of 'significant democratic shortcomings' in relation to watchdog, public sphere, community-building and communicative equality criteria. He advocates 'critical selectivity' over 'wholesale adoption' of Western media models (and democracy) in the South Pacific to avoid some 'entrenched shortcomings' of dominant Western media (p. 21) Hackett's views mirror concerns in some circles about the efficacy of a 'one-size fits all' approach. Such reservations have prompted calls for designing local training formulas that account for local conditions (K. Kumar, 2009), which is the premise behind the responsible reporting framework proposal.

Fiji has its own unique 'local conditions' to contend with, including an inherited Westminster democratic electoral system modified to include communal (race-based) voting and reserved positions for indigenous Fijian institutions that were authoritarian in nature. The aim was to stabilise Fiji's 'plural society', but melding traditional systems with modern ones had some negative side effects (see Lal, 1988; Lawson, 2004; Ravuvu, 1991).

When reflecting on media practice in Fiji's complex democratic framework (which has currently given way to military rule) two poignant questions posed by Hackett (2013, p. 34) come to mind:

1. Is the 'standard liberal' concept of press freedom the 'most useful normative guideline' for journalism in an emerging democratic polity?

2. What kind of journalism would help 'foster governance' that is 'stable and peaceful'?

\section{The context}

In Fiji and in the region, there has been remarkably little consistent research looking into the media-conflict dynamic, or the possibility of localised reporting frameworks. The focus has been on mistakes made by media, with nominal attention paid to possible interventionist strategies to address the situation (see, for example, Field, 2002; Gounder, 2006; Kiran, 2005; Mason, 2007; Parkinson, 2000).

Following independence in 1970, Fiji adopted a racially-based electoral system that encouraged the formation of racially-based rather than ideologically-based parties (Hagan, 1987). This has generally resulted in a 
largely indigenous Fijian government facing off against a mostly Indo-Fijian opposition. This formation resembles what Dorcella Bazahica (2001) refers to as 'negative solidarity'. It is based on ethnicity and regionalism, unlike 'positive solidarity', which is based on common ideology, and is a pre-condition for an enduring democracy. In a sense, 'negative solidarity' has been Fiji's Achilles heel as political conflict along ethnic lines worsened progressively. Fiji's politicians lacked the will to collaborate, with a top-down effect on the people. As veteran New Zealand journalist Michael Field (2010) correctly observed, Fiji's 'poison' was its politicians, who gave the nation its other slogan, 'coup coup land'.

While a small number of losing politicians and elites benefited from the coups, the rest of the country has suffered tremendously. The words of Paul Collier (2009) in his book Guns, Wars and Votes: Democracy in Dangerous Places, ring true for Fiji. As Collier said, 'Wars and coups are not tea parties: they are development in reverse' (p. 9). The Fiji coups can be linked to a trend of serious and sustained declinism that permeates virtually all levels of society. This includes investment falling from 25 percent of GDP in the 1970s to around 12 percent in recent years (Naidu, 2005, p. 373). The meagre annual average growth of 1.6 percent since 1996 reflects the high unemployment rate of 25.4 percent (B. Prasad \& R. Singh, 2008; Naidu, 2005).

In the face of such a calamity, whether media should re-examine their role and ethos in terms of conflict reporting, or stick to the old ways of doing things, is the essential thesis of this article.

\section{Media, coups and conflict in Fiji}

The dominant Anglo-American journalistic paradigm places a premium on conflict as a news value; bad news is good news or if it bleeds, it leads (Patterson, 1996, p. 17). The proposed responsible conflict reporting framework is premised on this writer's notion that the normal media-conflict dynamic is amplified in Fiji because of the country's ethnic make-up and racially-based political system. As MacWilliam (2001) says, Fiji's elections play a 'critical part' in producing racialist politics. In addition, Erik Larson's (2008) research shows that the nature of political reporting in Fiji indicates a 'bureaucratically-orientated' media existing as part of the country's larger political structure (pp. 14-27).

The above findings betray a symbiotic relationship between the Fiji 
media on the one side, and the political elite and their functionaries on the other. This resonates with Herman and Chomsky's (1988) propaganda theory whereby journalists are drawn to powerful sources of information by economic necessity and reciprocity of interests (p. 18). In terms of responsible conflict reporting, the level of uncritical media coverage given to politicians in Fiji is important. This is because politicians could have a vested interest in maintaining an ethnic divide in a country where politics is a 'zero-sum' game pursued via a 'scorched-earth policy', often to the 'detriment of society' (Kant, 2012).

One focus of the proposed responsible conflict reporting framework is to look at ways of enhancing journalist capacity as a buffer against media manipulation by the political elite. This and other aspects of the framework are discussed next.

\section{Responsible conflict reporting}

Professor Jacob Bercovitch (2005) has highlighted that sustainable conflict resolution is virtually impossible without a clear theoretical understanding, and that academics have an important role to play in providing practitioners with:

...broad conceptual frameworks or ideas that synthesise our research efforts and identify conditions conducive to the evolution of a conflict or its resolution. It is here in our theory-building role that we can provide broad interpretative information that allows policy makers to extrapolate trends and envisage possible developments even before they occur. (Bercovitch, 2005, pp. 63-66)

Such thinking underpins the proposed responsible conflict reporting framework, which incorporates insights drawn from communication development, peace-building, peace journalism and normative media, and political economy of the media theories. The key concepts include:

- Communitarianism (Ward, 2009, 2010)

- Deliberative journalism (Romano, 2010a)

- South Pacific Four Worlds News Values (Robie, 2013)

- Peace journalism (Lynch \& Galtung, 2010)

- Conflict sensitive reporting (Ross Howard, 2003; 2009)

- Use and abuse of media in vulnerable societies (Frohardt \& Temin, 2003)

- Development journalism (Romano, 2010a) 
Responsible conflict reporting conceptualises conflict as part of a larger framework shaped and influenced by historical as well as current factors, with long-term socio-economic and developmental implications. Consequently, responsible conflict reporting requires journalists to understand the history of their country, and its impact on present-day conflicts. Journalists should also be able to fully comprehend the damaging impact of conflict on socio-economic and developmental progress. Romano's (2010a) call for journalists with a 'more sophisticated' understanding of the 'consequences of their work' is well-placed. In Fiji, journalists may need to be sensitised to both the social and economic effects of conflicts. To contextualise, Fiji has a 20-year infrastructure deficit of F $\$ 3.4$ billion because of persistent conflict and instability (Prasad \& Narayan, 2008). Journalists first have to understand the significance of this shortfall in social and economic terms before they can properly report about it.

As such, a central idea behind the proposed responsible conflict reporting framework is that conflict should not be treated as any ordinary story, but handled with due care given its potentially-damaging, long-term effects. Another idea is that the structural causes of conflict-poverty, under-development, uneven development, and corruption - should receive sufficient media attention. Based on the discussions so far, this writer would describe responsible conflict reporting as:

The regular, sustained, informed, in-depth, pre-emptive and proactive coverage of conflicts, encompassing their structural causes and risk factors, with the aim of avoiding destructive escalation so as to facilitate progressive developments.

This approach requires a broadening of the traditional journalistic definition of conflict as a news value. Journalists would be obliged to pay attention to not just visible conflicts but also non-visible ones rather than wait for them to conflagrate before becoming 'newsworthy'. As Romano (2010b) points out, journalists usually overlook topics until they reach the 'scorching point of crisis' (p. 235).

Towards this end, responsible conflict reporting is informed by several concepts, which are discussed next.

\section{Communitarianism}

Communitarianism provides criticism of, and an alternative to, liberal theory 
(Christians, Fackler \& Ferre, 1993; Ward, 2009). It emphasises the 'restraining principles' of minimising harm and being accountable, and it promotes the ethics of care in attempts to restrain news media that are often insensitive to story subjects and sources (Ward, 2009, p. 300).

\section{Deliberation}

The responsible conflict reporting framework is inspired by Angela Romano's (2010a) comprehensive scholarly compilation on deliberative democracy, critical deliberative journalism, and development journalism. Deliberation is the 'discussion and consideration that is undertaken before a decision is made or an action is taken' (Romano, 2010c, p. 3). Romano holds that all forms of journalism, some more than others, can support deliberation in the following ways:

- Bring issues that affect community life to public attention, and help to sustain attention on those issues;

- Create reports that are 'sufficiently engaging to capture public attention' but are also 'incisive, comprehensive, and balanced so that the public can frame issues' and understand their background and implications;

- Ensure that reports 'identify and include the insights and contributions of all relevant stakeholders and actors in the situation';

- Investigate barriers preventing stakeholder participation in discussions;

- Check the quality of ideas and policies being discussed;

- Reveal attempts to manipulate public opinion;

- Report on communities as they evaluate potential responses;

- Investigate whether and how communities have acted upon decisions that result from deliberation (pp. 10-11).

'Four Worlds'news values

Robie's notions of 'Four Worlds' news values covers Indigenous minorities in dominant/imperialist nation states such as New Zealand, Australia, the Philippines, and also Bougainville in the context of the10-year civil war against Papua New Guinea (2008, 2013). Fourth world media values advocate for Indigenous rights, independent [political] voice, language, culture, education and solidarity (Robie, 2004; 2005). These news values could cover the 12,000 descendants of people from the Solomon Islands, Vanuatu and 
Papua New Guinea brought to Fiji during the blackbirding era from 1864 . This politically-powerless, landless, and voiceless group lags behind other groups, with around 90 percent living in poverty (Australian government refugee review tribunal, 2010). As a framework promoting social justice as a peace-building measure, responsible conflict reporting could draw from Robie's Four Worlds news values.

Peace journalism, conflict sensitive reporting, use/abuse of media in vulnerable societies

Peace journalism was founded by Swedish scholar Johan Galtung in the 1970s (Lynch \& Galtung, 2010). Lee (2010) defines peace journalism as a goal-oriented, non-objective and self-conscious promoter of peace while Blasé (2004) sees it as a proactive and purposeful way of conflict reporting. Critics of peace journalism describe it as dangerous, flawed, meaningless, squishy, subjective, misleading, unhelpful, prescriptive and impractical (Hanitzsch, 2004; 2008; Kovarik, n.d; Loyn, 2007). However, claims that peace journalism glosses problems are questionable since this would be counterproductive to its avowed goals. As Romano (2010d) says, if social divisions are ignored, then unresolved issues will simmer and disgruntled parties may express themselves in ways that intensify the tensions (p. 28).

Related to peace journalism are the conflict sensitive reporting and the use and abuse of media in vulnerable societies frameworks. They were respectively developed by Ross Howard (2003, 2009), and Mark Frohardt and Jonathan Temin (2003) to counter attempts by political elites to exploit media in 'vulnerable societies'. Some core ethics of the frameworks that could apply to Fiji include:

- Going beyond bare facts reporting

- Not blaming ethnicity

- Avoiding stereotyping, inflammatory language

- Better story selection, more insightful reporting

- Injecting context, appreciation for root causes

- Seeking, analysing and publicising possible solutions

- Quoting people who condemn violence

- Giving non-elite sources voice and space

Peace-building and development journalism synergies

Romano (2010d) has usefully identified five major interpretations of 
development journalism. Her second interpretation resonates with responsible conflict reporting. It highlights:

...journalists' nation-building role by encouraging 'positive' news stories about community development initiatives, such as attempts to bolster the economy, build stable societies, foster harmony within and between communities, and strengthen consensus between diverse groups. Such journalism would also report on crises and social problems, but in a way that identifies the causes and possible solutions, so that citizens are not overwhelmed by negative news that suggests their societies are being buried by intractable problems. (Romano, 2010d, p. 25)

The relevance of development journalism as a responsible conflict reporting measure for Fiji can be found in the works of Fijian sociologist Joeli Veitayaki (2008). He points out that support for Fiji's coup culture is especially strong among impoverished rural indigenous Fijians. Addressing their development needs could be the key to breaking the coup cycle (p. 39).

To be effective, media interventions need to be customised to local conditions, which are often unique in nature, as are the problems. This is addressed next, in the context of this project's research methodology, and a brief look at the results in terms of how they inform the responsible conflict reporting framework as it would apply to Fiji.

\section{Methodological framework}

A fundamental criticism against peace journalism frameworks is that they often jump from theorising to media reform without producing empirical data to inform and guide their initiatives (McMahon \& Chow-White, 2011). Such criticisms were considered by this project, and field research was undertaken to gather data in support of the proposed concept.

The mixed-methods approach included a major survey of the Fiji media landscape, a content analysis of the 2006 elections in the print media, and interviews with journalists, academics, civil society representatives and others in September-October last year and in February-March of this year. The research strategies are complementary in that the foundation on which media content is built and created is the structure/landscape of the media (Betz, 2011, p. 6). They also address the criticism that contemporary conflict reporting frameworks focus on individual journalists rather than on structures 
that support news selection and reporting procedures (Hanitzsch, 2004).

The research method was designed to detect the problem areas in terms of both media structure and journalist capacity, and identify opportunities for two forms of intervention: content-specific intervention and structural intervention. Content-specific intervention is based on studying media content and identifying areas in which journalists might need 'issues-based' training. Structural intervention seeks to detect weakness in media and journalist capacity and recommends how these can be addressed (Frohardt \& Temin, 2003). The research findings could provide clues about the shape and form of the proposed responsible conflict reporting framework, and how it could be implemented. Only a limited discussion of these aspects is possible at this stage of the project.

\section{Preliminary discussion of results and implementation}

A preliminary analysis of the final month of campaigning in Fiji’s May 2006 election as reported in the three national dailies-The Fiji Times, Fiji Sun and The Fiji Daily Post-lends weight to assertions that politicians engage in racialist politics (MacWilliam, 2001) and that there is a heavy reliance by journalists on politicians as news sources (Larson, 2008). In general, political rhetoric and logistical matters rather than issues dominated coverage. For example, the land issue, which has been linked to racial tension and instability in Fiji, and is crucial for the country's economic well-being, received far less coverage than the movements and activities of the international election observers. Consequently, a responsible reporting framework for Fiji would include training both student and professional journalists about the land problem. This would stop politicians from having a free hand in terms of portraying the issue to suit their agendas.

As Frohardt and Temin (2003) state, issues-based training increases the capacity for journalists to provide their listeners and readers with the information they need to address the underlying causes of economic or environmental problems, rather than stories that provide scapegoats and are thus misleading. Issues-based training topics will change over time, but at this stage in Fiji's history, militarisation and constitutionalism could be additional subjects for consideration given their link to instability.

Besides content-specific interventions, Frohardt and Temin (2003) recommend structural reforms as an effective strategy for strengthening a professional media sector, and protecting its content from biased influence, and obviating 
future attempts to manipulate the media during periods of social stress. Structural interventions can include:

- Developing journalist competence, such as academic qualifications, writing ability, editing skills, and contextual knowledge to counter efforts to incite conflict, as well as debunk some of the inflammatory myths and stereotypes propagated in the media

- Promoting diversity in the journalist corps and media ownership to minimise risk of abuse by members of the dominant group or groups in society

The national journalist/media survey undertaken by this study was modelled on Robie (2003) and Romano (1999). The Fiji media survey shows that most Fiji journalists do not have academic qualifications. Furthermore, they are relatively young, with a national mean age of about 26 , which is significantly lower than the global average journalist age of 39 (Weaver \& Willnat, 2012). The results show that Fiji has a relatively inexperienced and underqualified journalist corps trying to report on some weighty issues. Journalists' youth and inexperience is reflected in the content analysis where news reports parrot rather than challenge politicians.

The preliminary findings indicate that aside from issues-based training, strategies to retain journalists to build experience in newsrooms may be needed. Interviews by this writer showed keenness on the part of media companies to retain their best reporters. But often they are unable to match the salaries offered by the private sector, civil society organisations and government departments. Market forces, including the deadline-driven nature of the news business, are other impediments to responsible conflict reporting. There are no easy solutions, but if the media industry lacks capacity and resources, a concerted, coordinated and collaborative effort by government agencies, civil society organisations, educational institutions and the international community could provide technical expertise and knowledge, content and other forms of support. Scholarships could be used to attract candidates to the news media industry, where they could be retained with further opportunities for higher studies. Apart from staff retention, such initiatives could lead to better-qualified journalists. Interviews this writer had with publishers, editors and newsroom leaders showed that they were receptive to the idea of collaborating with government and civil society as long it was conducted at arm's length and did not compromise their independence. 


\section{Conclusion}

This article argues that there is a need to rethink journalism in general, and conflict reporting in particular in the Fiji and Pacific contexts, in light of an increase in conflicts in the post-colonial period. Recurring instability in Fiji and the rest of Melanesia has given rise to tags like 'arc of instability'. This article proposes a new approach to conflict reporting. The suggested responsible conflict reporting framework can be a seen as a response to the increase in social and political conflict in the region in the last two decades. It can also be regarded as a reaction to allegations that a commercially-orientated media treats conflict as a saleable commodity and that journalists tend to dramatise the action and violence in order to add value to the 'product'. The responsible conflict was proposed to, among other things, sensitise journalists to conflicts by making them more aware of their root and structural causes, and their devastating impact on Pacific societies. The article discussed the findings of this writer's Fiji-based study showing media's over-reliance on elite political sources, and the possible repercussions of this tendency. The paper posits responsible conflict reporting as a possible strategy to address these concerns. It stresses that the proposed concept needs to be operationalised in a free media environment rather than in an excessively legalistic, repressive and regulated setting.

\section{References}

AusAid. (2006). State, society and governance in Melanesia project - Conflict prevention in the Pacific. Retrieved on February 21, 2012, from http://rspas. anu.edu.au/papers/melanesia/research/SSGM_ConflictPreventioninthePacific_ ResearchPaper_06.pdf

Australian government refugee review tribunal. (2010). Country Advice-Fiji. Retrieved on January 18, 2013, from www.unhcr.org/refworld/pdfid/4f14257c2.pdf

Baba, T. (2005). Institutionalised conflict: A nation adrift. In J. Henderson \& G. Watson (Eds.), Securing a peaceful Pacific (pp. 365-369). Christchurch, NZ: Canterbury University Press.

Bainimarama: Free speech 'causes trouble'. (2009). TVNZ News. Retrieved on January 20, 2013, from http://tvnz.co.nz/world-news/bainimarama-free-speech-causestrouble-2646295

Bale, Q. (2003, May 7). Comments made at the Fiji Editors' Forum on the theme, 'Media Freedom, Our Responsibility', Suva.

Bazahica, B. (2001, January). Democratie, culture et ethnies. Paper presented at the World Social Forum, Porto Alegre. 
Bercovitch, J. (2005). The relevance of theory. In J. Henderson \& G. Watson (Eds.), Securing a peaceful Pacific (pp. 62-68). Christchurch, NZ: Canterbury University Press.

Bercovitch, J., \& Jackson, R. (2009). Conflict resolution in the 21st century: Principles, methods, and approaches. Ann Arbor: University of Michigan Press.

Betz, M. (2011). Conflict sensitive journalism: Moving towards a holistic framework. Denmark: International Media Support.

Blasé, B. (2004). Peace journalism and the news production process. Conflict and Communication Online, 3(1/2), 1-12.

Brislin, T. (1979). Media's role in Pacific Islands politics: A roundtable discussion. Paper prepared at a roundtable discussion on media and politics in the Pacific, University of Hawai'i at Manoa.

Brislin, T. (2004). Empowerment as a universal ethic in global journalism. Journal of Mass Media Ethics, 19 (2), 130-137.

Brislin, T. (2007, November 24). Empowerment as a universal ethic in global journalism. Paper presented at the United Nations University Global Seminar: Globalisation and Cultural Diversity, Kanazawa, Japan.

Chand, G. (2008). Looking forward. In B. V. Lal., G. Chand \& V. Naidu (Eds.), 1987: Fiji twenty years on (pp. 185-204). Lautoka: Fiji Institute of Applied Studies.

Chaudhry, M. (1999). Address at the launching of the [Fiji] Media Council General Media Code of Ethics and Practice, Suva, October 26.

Christians, C., Fackler, M., \& Ferré, J. (1993). Good news: Social ethics and the press. New York: Oxford University Press.

Collier, P. (2009). Wars, guns, and votes: Democracy in dangerous places. New York, NY: Harper Collins.

Devi, P. (1992). Print media in Fiji: Fostering democracy or ethnocracy? Suva, Fiji Islands: Fiji Institute of Applied Studies, Research Report No 2, University of the South Pacific.

Dibb, P. (2007, February). Australia's strategic outlook 2017-2027. Speech given at the Australian Defence Magazine (ADM) 2007 Conference, Australian National University, Canberra.

Dobell, G. (2003, February). The South Pacific: Policy taboos, popular amnesia and political failure. Paper presented at the Menzies Research Centre Lecture Series: Australian Security in the 21st Century, New Parliament House, Canberra.

Dobell, G. (2008). The strange saga of Speight's siege in Suva. In B. V. Lal \& M. Ptetes (Eds.), Coup (pp. 126-136). Canberra: Australian National University.

Ellis, D. (2012). 'Peace journalism' and deliberation. Retrieved on January 16, 2011, from www.middleeastmirror.com/peace_and_conflict/2012/01/09/democracy/ peace-journalism-and-deliberation/

Field, M. (2002). Pacific journalism: Reflections from a journalist in the field. In J. McGregor \& M. Comrie (Eds.), What's News?: Reclaiming journalism (pp. 233-243). Palmerston North: Dunmore Press.

Field, M. (2010, May 16). Cloud coup coup land. Sunday Star-Times. Retrieved on 
January 20, 2013, from www.stuff.co.nz/sunday-star-times/features/3699745/ Cloud-coup-coup-land

Firth, S. (2001). Revisiting Fiji's 1999 elections. The Journal of Pacific Studies, 25 (1), 1-8.

Frohardt M., \& Temin, J. (2003). Special report: Use and abuse of media in vulnerable societies. Washington, DC: United States Institute for Peace.

Galtung, J. (1986). On the role of the media in worldwide security and peace. In T. Varis (Ed.), Peace and communication (pp. 249-266). San Jose, Costa Rica: Universidad para La Paz.

Galtung, J. (1998). High road, low road: Charting the course for peace journalism. Track Two, 7(4). Retrieved on December 15, 2011, from http://ccrweb.ccr.uct. ac.za/archive/two/7_4/p07_highroad_lowroad.html

Gounder, C. (2006). The Fiji 2000 coup: A media analysis. Unpublished MA thesis, School of Communication Studies. Auckland: AUT University.

Green, M. (2009). Fiji's short-lived experiment in executive power-sharing - May December 2006 (Discussion Paper 2009/2). Retrieved on December 1, 2012, from http://ips.cap.anu.edu.au/ssgm/papers/discussion_papers/09_02_green.pdf

Hackett, R. (2013). Press freedom and communication rights: Some reflections on the kinds of journalism that democracy needs. Pacific Journalism Review, 19 (1), pp. 13-40

Hagan, S. (1987). Fiji: behind the coup. Arena, 79(June), 9-14.

Hamelink, C. (2008). Media between warmongers and peacemakers. Media, War and Conflict, 1(1), 77-82.

Hanitzsch, T. (2004). Journalists as peacekeeping force? Peace journalism and mass communication theory. Journalism Studies, 5(4), 483-95.

Hanitzsch, T. (2007). It should be okay to criticise even noble ideas - counterplea by Thomas Hanitzsch. Conflict and Communication Online, 6(2), 1-4.

Hegarty, D. (2003, July). Peace interventions in the South Pacific: Lessons from Bougainville and Solomon Islands. Paper presented at the Asia-Pacific Centre for Security Studies: Oceania at the crossroads, Honolulu.

Henderson, J., and Watson, G. (2005). Securing a peaceful Pacific. Christchurch: Canterbury University Press.

Herman, E., \& Chomsky, N. (1988). Manufacturing consent: The political economy of the mass media. London: Vintage.

Hirst, M., \& Patching, R. (2007). Journalism ethics: Arguments and cases: [2nd Ed]. South Melbourne: Oxford University Press.

Howard, M. (1991). State power and political change in Fiji. Journal of Contemporary Asia, 21(1), 78-106. doi:10.1080/00472339180000081

Howard, R. (2003). Conflict sensitive journalism: A handbook by Ross Howard. Vancouver, BC: Institute for Media, Policy and Civil Society and International Media Support.

Howard, R. (2009). Conflict sensitive reporting: State of the art. A course for journalists and journalism educators. United Nations Educational, Scientific and Cultural Organisation, Paris. 


\section{MEDIA AND DEMOCRACY IN THE PACIFIC}

Humphreys, M. (2002). Economics and violent conflict. Retrieved on February 2, 2013, from www.giz.de/Themen/en/dokumente/en-economics-and-violent-conflict.pdf

Iroga, R. (2008). Local media's role in peace building in post-conflict Solomon Islands. In E. Papoutsaki \& U.S. Harris (Eds.), South Pacific islands communication: Regional perspectives, local issues (pp.152-174). Singapore: Asia Pacific Information and Communication Centre/Nanyang Technological University.

Kant, S. (2012, December 1). Temporary folly. [Weblog message]. Retrieved on December 2, 2012, from http://crosbiew.blogspot.com.au/2012/12/temporaryfolly.html

Kiran, S. (2005). An analysis of the reportage of the May 2000 political crisis in The Fiji Times. Unpublished MA thesis. Suva: University of the South Pacific.

Kovarik, B. (n.d.). What has journalism ever done for peace? Retrieved on December 20, 2011, from www.radford.edu/ wkovarik/misc/blog/5journalism.peace.html

Kriesberg, L. (2007). Constructive conflicts: From escalation to resolution [3rd Ed.]. Lanham: Rowman \& Littlefield.

Kumar, K. (2009). One size does not fit all: Objectives and priority areas for media assistance in different societies. Accessed on January 20, 2013, from http://cima. ned.org/sites/default/files/Kumar\%20-\%20One\%20Size\%20Does\%20Not\%20 Fit\%20All.pdf

Lal, B. (1988). Power and prejudice: The making of the Fiji crisis. Wellington: Victoria University.

Lal, B. (2008). The loss of innocence. In B. V. Lal., G. Chand \& V. Naidu (Eds.), 1987: Fiji twenty years on (pp. 1-12). Lautoka: Fiji Institute of Applied Studies.

Larson, E. (2008). Reproducing disengagement: Citizens' orientations, the news media and democracy in Fiji. Fijian Studies: A Journal of Contemporary Fiji, $6(1 \& 2), 9-32$.

Latu, J. (2010). Political reform and the media in Tonga: An examination of cultural, political and media attitudes towards democratic reform in two Tongan newspapers. Unpublished MCS thesis. Auckland: AUT University.

Lawson, S. (2004). The military versus democracy in Fiji: Problems for contemporary political development. In R.J. May \& V. Selochan (Eds.), The military and democracy in Asia and the Pacific (pp. 131-147). Canberra, ACT: ANU Press.

Lee, S. T. (2010). Peace journalism: Principles and structural limitations in the news coverage of three conflicts. Mass Communication and Society, 13(4), 361-384.

Loyn, D. (2003, February 20). Witnessing the Truth. Open Democracy. Retrieved on January 27, 2012, from http:/www.opendemocracy.net/media-journalismwar/ article_993.jsp

Loyn, D. (2007). Good journalism or peace journalism? Conflict \& Communication Online, 6(2), 1-27. Retrieved on October 5, 2011, from www.cco.regener-online. de/2007_2/pdf/loyn.pdf

Lynch, J. (2006). What's so great about Peace Journalism? Global Media Journal: Mediterranean Edition, 1 (1), 74-87.

Lynch, J., \& Galtung, J. (2010). Reporting conflict: New directions in peace journalism. Brisbane: University of Queensland Press.

128 PACIFIC JOURNALISM REVIEW 19 (1) 2013 
MacBride, S. (1980). Many voices, one world: Report of the International Commission for the Study of Communication Problems, Paris: UNESCO.

MacWilliam, S. (2001). Shallow coups, thin democracy. The Journal of Pacific Studies, 25(1), 9-44.

Mason, A. (2007). Reporting the Fiji coups: Elite sources, journalistic practice and status quo. Pacific Journalism Review, 13(1), 107-23.

McMahon, R., \& Chow-White, P.A. (2011). News media encoding of racial reconciliation: Developing a peace journalism model for the analysis of 'cold' conflict. Media, Culture \& Society, 33(7), 989 - 1007.

Media in Fiji told to adopt 'journalism of hope'. (2009, April 17). Radio New Zealand News. Retrieved on August 29, 2012, from www.radionz.co.nz/news/world/6375/ media-in-fiji-told-to-adopt-'journalism-of-hope'

Moala, K. (2008). Media and conflict in the kingdom: The case of Taimi 'o Tonga. In E. Papoutsaki and U.S. Harris (Eds.), South Pacific Islands communication: Regional perspectives, local issues (pp.175-185). Singapore: Asia Pacific Information and Communication Centre/Nanyang Technological University.

Mody, B. (2011). Educating journalism students to do comprehensive reporting. Asia Pacific Media Educator, 22, 451-471.

Naidu, V. (2005). Underdevelopment and conflict. In J. Henderson \& G. Waston (Eds.), Securing a peaceful Pacific (pp. 370-3755). Christchurch, NZ: Canterbury University Press.

Naidu, V. (2008). Social consequences of coups in Fiji. In B. V. Lal., G. Chand \& V. Naidu (Eds.), 1987: Fiji twenty years on (pp. 155-171). Lautoka: Fiji Institute of Applied Studies.

Obijiofor, L. (2011). Peace and conflict reporting — strategies for knowledge sharing in Africa and the Pacific. The Journal of Pacific Studies, 31(2), 241-258.

Parkinson, T. (2000, June 3). Pens ready, Speight's army shoots to thrill. The Age.

Patterson, T. (1996). Bad news, period. Political Science and Politics, 29(1), 17-20.

Petley, J. (2011). Farewell fourth estate? Part 2-the press, the market and public interest. Retrieved on January 27, 2013, from http://inforrm.wordpress. com/2011/10/06/opinion-farewell-fourth-estate-part-2-the-press-the-market-andpublic-interest-julian-petley/

PMCF. (2005). Informing citizens: Opportunities for media and communications in the Pacific. [Report]. PMCF/AusAID, Canberra.

Prasad, B.C. \& Narayan, P.K. (2008). Reviving growth in the Fiji Islands: Are we swimming or sinking? Pacific Economic Bulletin, 23(5), 5-26.

Prasad, B., \& Singh, R. (2008). A survey of labour demand and employment opportunities in Fiji, Research Report. Fiji: Ministry of Labour.

Ravuvu, A. (1991). The facade of democracy: Fijian struggles for political control, 1830-1987. Suva: Reader Publishing House.

Rika, N. (2009). Unpublished speech, Pacific Islands News Association (PINA) convention, Port Vila, Vanuatu, Monday, July 27, 2009. Retrieved on July 18, 2012 , from www.mediafire.com/?yjxdvnmlylw 
Robertson, R. (2008). Ethnicity, development, \& coups: A history of postcolonial frustration. In B. V. Lal., G. Chand \& V. Naidu (Eds.), 1987: Fiji twenty years on (pp. 173-203). Lautoka: Fiji Institute of Applied Studies.

Robertson, R., \& Sutherland, W. (2001). Government by the gun: The unfinished business of Fiji's 2000 coup. Sydney, NSW: Pluto Press Australia.

Robie, D. (2003). Journalism education in the South Pacific, 1975-2003: Politics, policy and practice. Unpublished doctoral dissertation. Suva: Department of History/Politics, University of the South Pacific.

Robie, D. (2004). Mekim Nius: South Pacific media, politics and education. Suva: University of the South Pacific Book Centre.

Robie, D. (2005). South Pacific notions of the fourth estate: A collision of media models, culture and values. Media Asia, 32(2), 86-94.

Robie, D. (2008). Media and development in the Pacific: Reporting the why, how and what now. In S. Singh \& B. Prasad (Eds.), Media and development: Issues and challenges in the Pacific Islands (pp. 11-26). Lautoka: Fiji Institute of Applied Studies. Auckland: Pacific Media Centre.

Robie, D. (2011). Conflict reporting in the South Pacific: Why peace journalism has a chance. The Journal of Pacific Studies, 31(2), 221-240.

Robie, D. (2013). 'Four Worlds' news values revisited: A deliberative journalism paradigm for Pacific media. Pacific Journalism Review, 19(1), 84-110.

Robie, D. (2013). 'Four Worlds' news values revisited: A deliberative journalism paradigm for Pacific media. Pacific Journalism Review, 19(1), 84-110.

Romano, A. (1998). Normative theories of development journalism: State versus practitioner perspectives in Indonesia. Australian Journalism Review, 20 (23), 60-87.

Romano, A. (Ed.). (2010a). International journalism and democracy: Civic engagement models from around the world. New York: Routledge.

Romano, A. (2010b). Ongoing issues for deliberative journalism. In A. Romano (Ed.), International journalism and democracy: Civic engagement models from around the world (pp. 231-242). New York: Routledge.

Romano, A. (2010c). Deliberation and journalism. In A. Romano (Ed.), International journalism and democracy: Civic engagement models from around the world (pp. 3-15). New York: Routledge.

Romano, A. (2010d). Deliberative journalism: American public journalism versus other international media models. In A. Romano (Ed.), International journalism and democracy: Civic engagement models from around the world (pp. 16-31). New York: Routledge.

Schramm, M. (2003, June 6). Letters to the editor. The Fiji Times, p. 6.

Singh, S. (2010). Life under Decree No. 29 of 2010: The Fiji Media Development Decree. Pacific Journalism Review, 16(2), 147-162.

Singh, T. R. (2011). The 2000 Speight coup in Fiji: An analysis of the role of The Fiji Times and the impact of partisan media. Unpublished Masters dissertation. Auckland: School of Communication Studies, AUT University.

Veitayaki, J. (2008). Breaking Fiji coup culture through effective rural development. 
In B. V. Lal., G. Chand \& V. Naidu (Eds.), 1987: Fiji twenty years on (pp. 39-56). Lautoka: Fiji Institute of Applied Studies.

Ward, S. J. (2009). Journalism ethics. In K. Wahl-Jorgensen \& T. Hanitzsch (Eds.), The handbook of journalism studies (pp. 295-309). New York, NY: Routledge.

Ward, S. J. (2010). Global journalism ethics. Montreal: McGill Queens University Press.

Weaver, D. H., \& Willnat, L. (Eds.). (2012). The global journalist in the 21st century (2nd ed.). New York: Routledge.

Wolfsfeld, G. (1997). Promoting peace through the news media: Some initial lessons from the Oslo peace process. Harvard International Journal of Press/Politics, 2(4), 52-70.

Zenebe, B. (2012). The role of media in ethnic violence during political transition in Africa: The case of Rwanda and Kenya. Unpublished doctoral dissertation. Lincoln: The University of Nebraska.

Shailendra Singh, a former head of journalism at the University of the South Pacific in Suva, Fiji, is currently a PhD candidate at the University of Queensland. His research focus is on conflict reporting in Fiji and the Pacific. Singh has published extensively on Pacific Island media and development issues, both as a journalist and as an academic. He is grateful to Dr Angela Romano of QUT for an advance copy of her publication, International journalism and democracy: civic engagement models from around the world (2010). He is also grateful to Professor David Robie of AUT, Professor Robert Hackett of Simon Fraser University, Professor Biman Prasad and Dr Rup Singh, both of USP, for advance copies of their papers; and to Dr Som Prakash for his insightful feedback.

shailendra.singh@uqconnect.edu.au 